sui de scaccario salutem et fidelia semper seruicia. Nouerit vestra dominacio ${ }^{1}$ quad scrutatis ad mandatum vestrum Rotulis scaccarii vestri de Recepts et Brevibus : Inuentum est quod ismpridem debebatis diuersis mercatoribus de Ipr' mille quaterviginti decem libras decem et septem solidos et quatuor densrios. De quibus receperunt ad ipsum scaccarium sexaginta libras tantum. Et sic debentur eisdem adhuc ! mille et triginta libre decem et septem solidi et quatuor denarii secundum tenorem breuium de Liberate que retroactis temporibus ad ipsum scaccarium sunt exhibita et adhuc remanent in eodem. Bi autem ipsam pecuniam uel partem eiusdem alibi uel aliunde receperint ! nescimus. Ad hec de centum marcis liberandis nunciis vestris ad partes transmarinas profecturis vt mandastis, nichil omnino facere possumus quia in vltimo recessu vestro a Westmonasterio : tulerunt Custodes Warderobe vestre vobiscum quod non credimus vos latere quicquid tunc habuimus in Thessuro videlicet mille marcas preter pecunia[m] que [sic] prius liberaueramus in eadem Warderoba. Et ad operaciones Westmonasterii et ad empciones eiusdem Warderobe vestre et alibi per precepta vestro specialia : [e]t post ipsum recessum vestrum est vnicus denarius receptus in eodem scaccario preter quandam partem tallagii quod domine Regine assignastis quod non transit per manus nostras immo per manus clericorum suorum ad hoc specialiter deputatorum. Et quidem contra festum translacionis beati Esdwardi proximo preteritum recepimus a diuersis mercatoribus et Iudeis octingentas marcas de quibus nichil adhuc reddidimus nec est aliquis modo qui nobis aliquid nomine mutui tradere velit. Et sic nichil facere possumus nunciis predictis : quod nobis est molestissimum. conseruet vos dominus.

\title{
The Channel Islands Petitions of 1305
}

IT will be remembered that in his introduction to the Memoranda de Parliamento the late Professor Maitland discussed the question of the completeness of the roll there printed (now Exchequer Parliament Roll 12) and showed that in its present form it is imperfect. He mentioned in particular (p. xxiii) the omission of the petitions from Gascony, for which receivers had been appointed, and also the omission of petitions relating to four matters which are dealt with in the Placita at the end of the roll. These are the Ordinance of Trailbastons, the dispute between the priors of Durham and Coldingham, proceedings against the abbot of Mont St. Michel, and procoedings against the men of Dover; but the dispute between the priors is dealt with in a membrane formerly numbered T. G. 40461, now incorporated in the roll, and printed by Maitland (pp. $314 \mathrm{ff}$.). Another notable deficienoy is the absence of any petitions from the Channel Islands. The roll mentions that John de Berewyk, Hervey de Staunton, William de Dene, William de Mortimer, and Roger de

Interlined. 
Beaufoy were appointed to hear petitions from Ireland and the Isle of Guernsey (p. 4). The Irish petitions are found on pp. 232-54, but none appear from any of the Channel Islands. It is also noticeable that one of the three questions dealt with in the Placita and not elsewhere in the roll is that relating to the abbey of Mont St. Michel, which ought to be mentioned among these petitions.

It does not appear to have been noticed that there is a document in the Bibliothèque Nationsle at Paris which does fill this gap and does deal with the abbey of Mont St. Michel. This is MS. Lat. 9215, Mont St. Michel, no. 7, and was printed in 1878 by M. Julien Havet in his Cours Royales des hles Normandes in the appendix (pp. 197-205). It is headed

Peticiones Insularum de Jereseye et Gernereye in parliamento domini regis apud Westmonasterium die dominica proxima post festum sancti Mathie Apostoli, anno regni regis Edwardi filii regis Henrici tricesimo tercio and ends

Responsiones facte ad peticiones Hibernie et Insularum Jereseye et Gurneseye exhibitas coram J. de Berewyk, H. de Staunton, Willelmo de Dene, Willelmo de Mortimer et Rogero Beaufou quos rex assignavit ad huiusmodi peticiones recipiendas, \&c.

This corresponds with the list of auditors given in the roll. ${ }^{1}$ It was, therefore, reasonable to suppose that this document was either a transcript of some missing membrane of our Exchequer Parliament Roll 12, or the missing part itself. I accordingly consulted M. Charles Bémont on this subject, and he has most kindly inspected the Paris manuscript on two separate occasions, and has compared it with a photostat copy of a part of the Parliament Roll (the upper portion of $\mathrm{m}$. 12, containing the Irish petitions, which should naturally precede those from the Channcl Islands). He has also most kindly enabled me to get a similar copy of the Paris manuscript.

On first inspecting the msnuscript, M. Bémont considered that it probably was a fragment of the Parliament Roll : and comparison with the photostat strongly confirmed this view. The size and form of the document agree with those. of the facsimile: the writing, the spacing, and the marginal marks correspond exactly. There is a hole (apparently for a filing-cord) in the document which corresponds with one in $\mathrm{m} .12$ of the Parliament Roll. This hole does not occur on the other membranes : but, although one would have expected such a schedule to be attaohed by sewing rather than by filing on a cord, it is possible that the Channel Islands petitions were attached to the Irish ones as a schedule, especially as the Paris manuscript 
shows no traces of needle-marks. It seems clear that the Paris manuscript is either a fragment of the Parliament Roll or a transcript by the same scribe of a part now lost. It remains to be considered how it came to its present resting-place. Little sems to be known of the history of the documents among which it is now to be found : but they all relate to Mont St. Michel. The proceedings against the abbot of Mont St. Michel form the subject of the longest of the petitions included in this document. It may be assumed, therefore, that before the roll was sewn up, the Guernsey membrane was detached and sent to Mont St. Michel as evidence in connexion with this dispute. It may of course be a transcript : but that does not explain how this particular membrane comes to be missing, nor why so much irrelevant matter was copied, nor why it corresponds so exactly with the other membranes in such essential matters as the spacing of the lines. The coincidence of the filing holes on this document and the membrane which should immediately precede it on the roll is also remarkable. The evidence in favour of identifying the Paris manuscript with a missing part of our Exchequer Parliament Roll cannot be regarded as conoluaive, but the balance of probability this view is supported by the authority of M. Bemont.

R. L. Atkrnsor.

\section{A List of Original Papal Bulls and Briefs in the Department of Manuscripts, British Museum}

\section{PART II}

\section{INNOCENT VIII (1484-92)}

237. Rome, St. Peter's, 6 August 1487. Permizsion for malefactors taking refuge in sanctuaries and issuing thence to commit thefte, homioides, dc., to be taken out of sanctuary at the bidding of the king of England or his officers. Frrst LINE. Ad perpetuam rei memoriam. Silk threads of bulla. 'Romanum decet Pontificem'. [Wilkins, Concilia, iii. 621-2.] Cleop. E. iii, fos. $135 \mathrm{~b}-6$.

238. Rome, St. Peter's, 20 September 1491. Confirmation of sale, by resson of its inconvenient distance from the hospital, of certain property of hospital called 'del Rey', administered by abbess of Las Huelgas without the walls of Burgos; the said property being in diocese of Toledo. FTRST unse. Ad perpetuam rei memoriam. Bulla ; silk. 'Licet ea que'. Add. Ch. 24815.

I I am greatly indebted to my collengues in the Public Recard Office, especially Mesan. Hubert Hall and Charles Johnson, for advice and csaistance in this matter : and I am particularly gratefol to $M$. Bemont for the very grest pernonal trouble he has teken to answer my inquiries 